\title{
Carrie Noland
}

Voices of Negritude in Modernist Print: Aesthetic Subjectivity, Diaspora, and the Lyric

Regime. New York: Columbia University Press, 2015. 326 pp. (Cloth US\$55.00)

Voices of Negritude in Modernist Print explores the works of the Negritude poets (mainly Aimé Césaire and Léon-Gontran Damas) from an interesting angle, namely the typosphere or the awareness that modernist poetry in its print form should render the oral heritage and the rhythms of the spoken words and sounds visually. Carrie Noland, the author of several excellent articles on Césaire and Damas, ${ }^{1}$ uses and indeed reinvigorates Jacques Rancière's notion of "embodiment," which can find different applications depending on whether you think of people actually crowding around a story-teller or poet or the subtle intimacy created by the written word.

Chapter 1 discusses different versions of Césaire's Cahier d'un retour au pays natal, and explains the neologism "verrition" as a reference to taste and the "double jouissance" of repeating over and over, "licking" the words as it were. Chapter 2 provides a close reading of Césaire's Et les chiens se taisaient. While a first version was finished in 1946, he continued to revise it, and the 1956 version was intended to function as a play for both radio and the stage. The fact that it was rewritten several times may either point to Césaire's dissatisfaction or testify to a "mobile" text.

The most interesting chapters concern Damas's way of subvocalizing the poem (a question that Julie Huntington had already explored in Sounding Off, a regretfully missing reference). Influenced by Harlem Renaissance poets such as Claude MacKay and Langston Hughes, Damas, as Noland convincingly argues, was also familiar with Vladimir Mayakovsky's "verse scalier" as translated into French by Louis Aragon, in which words are scattered on the page, suggesting the lyrical voice's fragmentation. In the chapter on rhythm in Damas's writing, Noland calls on critics such as Henri Meschonnic and Perry Phelan to trace an interesting parallel between poems by Jacques Prévert and Damas. Aragon and Prévert published in Soutes, a socialist journal; both were members of "la Section française de l'Internationale ouvrière"; and both wrote poetry that appealed to a large readership, thereby bridging mass and elitist culture.

The final chapter turns to language in Martinique and Césaire's debt to Guillaume Apollinaire. Césaire, Damas, and Senghor knew of Blaise Cendrars's

1 For example, "Graffiti and the Reinvention of Space," in Claus Clüver et al. (eds.), Orientations, Space/Time/Image/Word, (2005), pp. 305-17; "Poésie et typosphère chez Léon-Gontran Damas," in Céline Pardo et al. (eds.), Poésies et médias (XX ${ }^{e}-X X I^{e}$ siècles) (2012), pp. 131-54.

(C) KATHLEEN GYSSELS, 2017 | DOI: 10.1163/22134360-09101036 
prose and poems and Apollinaire's Calligrammes. Why didn't they go further in their experiment with layout? Damas probably intended to be much bolder, but his publishers cut his aspirations short as they would have involved producing deluxe editions. Writing poetry that would serve as a "plaque commémorative" for the deceased, Damas relied on Guy Lévis Mano. Unfortunately, G.L.M. was his publisher only twice, and due to the attacks launched against Pigments and Retour de Guyane, Damas might have been intimidated or even rejected by his first publisher for Graffiti and Névralgies. He then turned to more prestigious but less innovative publishers such as Pierre Seghers. Although famous for his protective and mediatory role for poets in the Resistance, foreigners, and nonFrancophone voices, Seghers was actually fairly conventional when it came to the "typosphere." G.L.M. was primarily a typographer and graphic designer fascinated by the latest fonts and their use in editorial design. The effect of changes in font and size has indeed remained a poor area of Damas criticism.

While Noland explores a wealth of material, one wishes that she had not limited her examples to the Notebook and a few well-known poems from Damas's first collection; Black-Label (published by Gallimard in 1956) would have offered plenty of interesting material. Indeed, it is here that Damas explores different fonts for certain words (like "scandal," written in English). The book's appendix offers Noland's translation of several of Damas's poems. Yet translations of the Pigments collection are already available (by Conroy Kennedy, Alexandra Lillehey, and Femi Ojo-Ade). Chapter 5 takes us back to the famous debate opposing Césaire to Louis Aragon, the "Red Front" to the "Black Front," the old debate about style and realism already to be found in René Ménil's plea against Léonard Sainville and Joseph Zobel's naturalism and "populism." In contrast to Édouard Glissant's plea for opacity, Aragon believed poetry should be transparent and prose descriptive in order to serve the masses. This is precisely what Caribbeans like René Depestre rejected, relying instead on magical realism. All in all, this is a remarkable piece of scholarship that brings up the tensions and contradictions between writers coming from various parts of the French Empire and publishing at a time that was rife with paradoxes.

\section{Kathleen Gyssels}

Francophone \& Postcolonial Literatures, Universiteit Antwerpen, B 2000 Antwerp, Belgium

kathleen.gyssels@uantwerpen.be 